\title{
Chickpea production and soil chemical attributes after phosphorus and molybdenum fertilization
}

\author{
Produção de grão-de-bico e atributos químicos do solo após a \\ adubação fosfatada e molíbdica
}

\author{
Rodinei Facco Pegoraro ${ }^{*}$, Maria Nilfa de Almeida Neta', Cândido Alves da Costa', \\ Regynaldo Arruda Sampaio', Luiz Arnaldo Fernandes', Márcio Neves Rodrigues ${ }^{1}$
}

\author{
${ }^{1}$ Universidade Federal de Minas Gerais/UFMG, Montes Claros, MG, Brasil \\ ${ }^{*}$ Corresponding author: rodinei_pegoraro@yahoo.com.br \\ Received in May 16, 2018 and approved in September 28, 2018
}

\begin{abstract}
Chickpea is the third most cultivated legume in the world. In Brazil, cropping of this legume is recent and definitions of fertilizer management techniques are scarce. In this study, the objective was to evaluate chickpea (BRS Aleppo) production and soil chemical attributes with and without phosphorus fertilization and leaf-applied molybdenum. A randomized block experimental design was used, with four replications. A 2 × 5 factorial arrangement was used to evaluate production, consisting of two molybdenum fertilization management practices (with and without molybdenum) and five application rates of $\mathrm{P}_{2} \mathrm{O}_{5}\left(0,60,120,180\right.$, and $\left.240 \mathrm{~kg} \mathrm{ha}^{-1}\right)$ in the form of single superphosphate. Soil sampling for evaluation of soil chemical attributes in the crop row and between rows was also considered. Molybdenum fertilization brought about greater stem and aboveground dry matter. Phosphorus fertilization increased stem, leaf, and seed yield, yielding a maximum of 2.83 t ha ${ }^{-1}$ seed at the rate of $200 \mathrm{~kg} \mathrm{ha}^{-1} \mathrm{P}_{2} \mathrm{O}_{5}$. However, maximum agronomic efficiency (8.30) was observed with the addition of $150 \mathrm{~kg}$ ha ${ }^{-1} \mathrm{P}$. Soil in the crop row attained higher concentrations of $\mathrm{P}, \mathrm{K}, \mathrm{H}+\mathrm{Al}$, and $\mathrm{P}$-rem and reduction in $\mathrm{pH}$, Ca concentration, $\mathrm{SB}, \mathrm{T}$, and $\mathrm{V}$ compared to between rows. Phosphorus rates reduced soil $\mathrm{pH}$ and increased $\mathrm{T}$ and the $\mathrm{P}$ concentrations, though only in the plant row. Between the rows, no changes were observed in soil chemical attributes, indicating low mobility of $\mathrm{P}$ and the acidification capacity of superphosphate in alkaline soils.
\end{abstract}

Index terms: Cicer arietinum L.; single superphosphate; seed yield.

\begin{abstract}
RESUMO
O grão-de-bico é a terceira leguminosa mais cultivada no mundo. No Brasil cultivos com essa leguminosa são recentes e definições de técnicas de manejo de fertilizantes são escassas. Objetivou-se avaliar a produção de grão-de-bico (BRS Aleppo) e os atributos químicos do solo sob doses de fósforo e molibdênio foliar. O delineamento utilizado foi em blocos ao acaso, com quatro repetições. Para avaliação da produção, adotou-se o esquema fatorial 2 × 5, consistindo de dois manejos da adubação, com ou sem molibdênio e cinco doses de $\mathrm{P}_{2} \mathrm{O}_{5}(0,60,120,180$ e $240 \mathrm{~kg} \mathrm{ha}^{-1}$ ). Para avaliação dos atributos químicos do solo, considerou-se também a amostragem na linha e entre linha de semeadura. A adubação molíbdica propiciou maior massa seca de ramos e da parte aérea. As doses de fósforo aumentaram a massa seca de ramos, folhas e grãos, obtendo-se a produção máxima de 2,83 t ha-1 de grãos na dose $200 \mathrm{~kg} \mathrm{ha}^{-1}$ de $\mathrm{P}_{2} \mathrm{O}_{5}$. Entretanto a máxima eficiência agronômica (8,30) foi observada com a adição de 150 kg ha-1 de P. No solo da linha de cultivo obteve-se maiores teores de $\mathrm{P}, \mathrm{K}, \mathrm{H}+\mathrm{Al}$ e $\mathrm{P}$-rem, e diminuição do $\mathrm{pH}$, teor de Ca, SB, T e V, em comparação àquele da entre linha. As doses de fósforo reduziram o pH do solo, aumentaram a T e os teores de $\mathrm{P}$, somente na linha de cultivo, indicando a baixa mobilidade do P e a capacidade de acidificação do superfosfato em solos alcalinos.
\end{abstract}

Termos para indexação: Cicer arietinum L.; superfosfato simples; produção de grãos.

\section{INTRODUCTION}

Chickpea (Cicer arietinum L.) is the third most cultivated legume in the world. India stands out as one of the largest producers and consumers of its seeds (or seed); however, its production is insufficient to meet the needs of the internal market, and chickpea imported (Bidyarani et al., 2016). It is recognized as a legume with high concentrations of proteins, nutrients, and carbohydrates (Laranjo; Alexandre; Oliveira, 2014). It is adaptable to wide climatic variation, has low production cost, and promotes biological fixation of atmospheric nitrogen (Nascimento, 2016; Artiaga et al., 2015; Balai et al., 2017). In Brazil, the semi-arid region has high production potential; however, this production is limited by lack of knowledge of adequate crop management conditions.

Phosphorus fertilization is among the main practices of crop management; yet, it is considered complex in tropical soils because of the high capacity of phosphorus for covalent adsorption to soil oxides (Gazola et al., 2013) and because of low natural availability of $\mathrm{P}$ to plants. In 
chickpea, balanced phosphorus nutrition is fundamental for establishing symbiosis with $\mathrm{N}_{2}$ fixing rhizobacteria, and it stimulates nodulation, initial development of roots, plant growth, and seed yield and quality, among other aspects (Balai et al., 2017). Neenu et al. (2014) affirm that fertilization with $60 \mathrm{~kg} \mathrm{ha}^{-1}$ of $\mathrm{P}_{2} \mathrm{O}_{5}$ is sufficient for maximum production of chickpea seeds in a Vertisols in India. Das et al. (2008) also reported a positive effect on relative growth rate, dry matter accumulation, nodulation, yield, and harvest index with application of $60 \mathrm{~kg} \mathrm{ha}^{-1}$ of $\mathrm{P}_{2} \mathrm{O}_{5}$. Economical efficiency and high degree of protein are reported by Singh and Singh (2012) using this same phosphorus application rate.

Phosphate fertilization, together with other nutrients such as molybdenum (Mo), can maximize legume yield. Bhuiyan et al (2008) and Togay, Togay and Dogan (2008a) obtained maximum seed yield and aboveground biomass production of mung bean and lentils, respectively, after using phosphorus application rates associated with molybdenum fertilization. Fertilization with $\mathrm{P}$ and Mo also had a positive effect on edible bean and soybean yield in areas of the Brazilian Cerrado (Araújo et al., 2009; Matoso; Kusdra, 2014; Vieira et al., 2016; Oliveira et al., 2017).

Molybdenum favors agricultural production by acting in plants as a cofactor of enzymes that participate in nitrogen metabolism, and participates as a constituent of the enzymes nitrogenase and nitrate reductase (Taiz; Zeiger, 2013), essential in assimilation of $\mathrm{N}$ by plants, indicating their potential as fertilizers for chickpea crops.

In light of the above, studies that seek to understand the yield capacity of chickpea in tropical soils fertilized with $\mathrm{P}$ and Mo are indispensable for definition of adequate management techniques. The aim of this study was to evaluate chickpea yield and soil chemical attributes under different application rates of phosphorus and molybdenum.

\section{MATERIAL AND METHODS}

The experiment was conducted from April to August 2016 in an area in the municipality of Montes Claros, MG, Brazil, located at $16^{\circ} 40^{\prime} \mathrm{S}$ and $43^{\circ} 50^{\prime} \mathrm{W}$, characterized as As semiarid tropical by the Köppen classification, with a dry summer (Alvares et al., 2013). The climate data during the time of the experiment are represented in Figure 1. The soil of the area is classified as a Haplic Cambisol, with medium texture. In the initial phase of the study, soil samples were collected from the $0-20 \mathrm{~cm}$ depth layer for chemical characterization, with the following results - organic matter (OC): 3.08 dag kg$^{-1}$; $\mathrm{pH}\left(\mathrm{H}_{2} \mathrm{O}\right): 7.5 ; \mathrm{P}$ (Mehlich 1): 3.51 $\mathrm{mg} \mathrm{dm}{ }^{-3}$; K(Mehlich 1): $142 \mathrm{mg} \mathrm{dm}^{-3}$; Ca: $7.6 \mathrm{cmol}_{\mathrm{c}} \mathrm{dm}^{-3}$; $\mathrm{Al}(\mathrm{KCl}): 0.0 \mathrm{cmol}_{\mathrm{c}} \mathrm{dm}^{-3} ; \mathrm{H}+\mathrm{Al}: 0.78 \mathrm{cmol}_{\mathrm{c}} \mathrm{dm}^{-3}$; SB: $10.36 \mathrm{cmol}_{\mathrm{c}} \mathrm{dm}^{-3}$; $\mathrm{t}: 10.36 \mathrm{cmol}_{\mathrm{c}} \mathrm{dm}^{-3}$; base saturation (V\%): 93\%; and T: $11.14 \mathrm{cmol}_{\mathrm{c}} \mathrm{dm}^{-3}$.

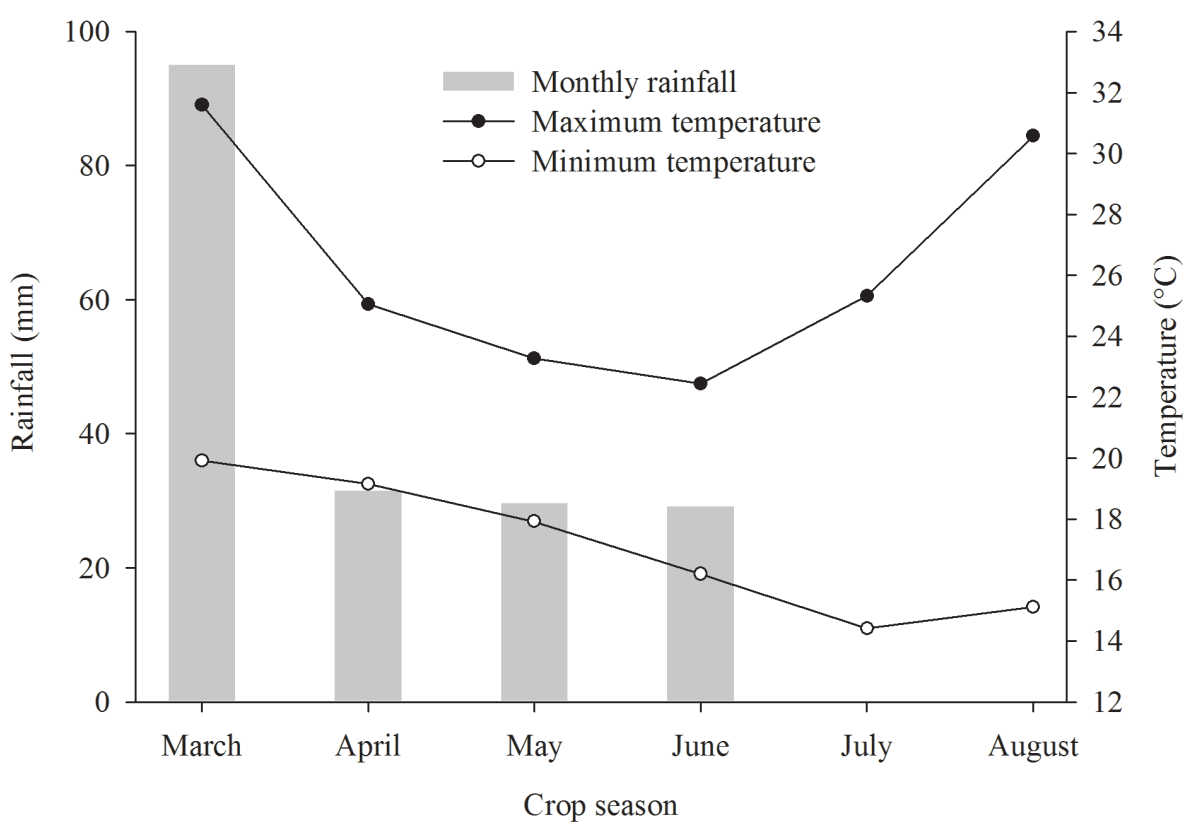

Figure 1: Rainfall, maximum and minimum temperature in the month in the chickpea crop season. 
A randomized block experimental design was used, with four replications, in a $2 \times 5$ factorial arrangement. The first factor represented the absence and presence of molybdenum at the rate of $80 \mathrm{~g} \mathrm{ha}^{-1}$ (ammonium molybdate); and the second factor consisted of the five phosphorus application rates: $0,60,120$, 180 , and $240 \mathrm{~kg} \mathrm{ha}^{-1} \mathrm{P}_{2} \mathrm{O}_{5}$ (single superphosphate). The phosphorus reference dose corresponded to $120 \mathrm{~kg} \mathrm{ha}^{-1}$, recommended for the highest technological level $\left(\mathrm{NT}_{4}\right)$ in bean cultivation, according to Chagas et al. (1999), since there are no consolidated studies indicating the recommended dose of $\mathrm{P}_{2} \mathrm{O}_{5}$ in Brazilian tropical soils for the cultivation of chickpea. The soil chemical attributes were analyzed at the end of the harvest as a factorial; soil samples were collected in the row and between the plant rows, and then the interactions among molybdenum application, soil sample location, and phosphorus application rates $(2 \times 2 \times 5)$ were examined.

Soil conventional tillage was performed by plowing and disking. Seeding was done with the application of 15 seeds per meter, with a $0.5 \mathrm{~m}$ spacing between plant rows. Thereafter was kept only 10 plants per meter, totalizing 200,000 plants ha ${ }^{-1}$. Before sowing, the seeds were inoculated with commercial peat material for edible bean at a concentration of $1 \times 10^{9} \mathrm{CFU}$ of Rhizobium tropici, under the recommendation for use of $4 \mathrm{~g}$ of the material for every $1 \mathrm{~kg}$ of seeds. The cultivar used was BRS Aleppo of the kabuli group, with semiupright growth habit, recommended for growing in the dry season (Nascimento et al., 2014).

Fertilization with $\mathrm{P}$ was carried out one week before sowing, in accordance with each established application rate. Fertilizer was applied in topdressing near the plant row (approximately $5 \mathrm{~cm}$ distant from the plants) at 20 days after emergence (DAE) with 65 $\mathrm{kg} \mathrm{ha}{ }^{1}$ of $\mathrm{N}, 20 \mathrm{~kg} \mathrm{ha}^{-1} \mathrm{~K}$, and $10 \mathrm{~kg} \mathrm{ha}^{-1} \mathrm{Mg}$, using urea, potassium chloride, and magnesium sulfate as sources, respectively. The fertilization used in the cultivation of chickpea followed the recommendation proposed by Chagas et al. (1999) for bean culture. In addition, in this period, $80 \mathrm{~g} \mathrm{ha}^{-1}$ of molybdenum was applied to the leaves in the form of ammonium molybdate. The molybdenum foliar application was performed with a coastal sprayer, using a spray volume equivalent to $200 \mathrm{~L} \mathrm{ha}^{-1}$. The micronutrients $\mathrm{B}, \mathrm{Cu}, \mathrm{Fe}$, and $\mathrm{Zn}$ were applied to leaves at 30 and $50 \mathrm{DAE}$ at the proportion of $0.2 \%$ boric acid $\left(0.34 \mathrm{~g} \mathrm{~L}^{-1} \mathrm{~B}\right), 0.2 \%$ copper sulfate $\left(0.26 \mathrm{~g} \mathrm{~L}^{-1} \mathrm{Cu}\right), 0.2 \%$ ferrous sulfate $\left(0.38 \mathrm{~g} \mathrm{~L}^{-1} \mathrm{Fe}\right)$, and $0.2 \%$ zinc sulfate $(0.40$ $\left.\mathrm{g} \mathrm{L}^{-1} \mathrm{~B}\right)$, respectively.
Plant health treatments and irrigation were carried out according to crop needs and technical recommendations for the crop in the region, as indicated by Nascimento (2016). A micro-spray irrigation system was used, with irrigation frequency of every four days. When necessary, weed growth was controlled manually.

At the end of the crop cycle, the twelve central plants in each plot were evaluated in regard to dry matter weight of plant parts: leaves, stems, seeds (corrected humidity in $13 \%$ ), and shoot plant parts), 100 seed weight, number of seed per plant, and Agronomic efficiency, expressed by the following Equation 1:

$$
A E=\frac{\mathrm{YFT}-\mathrm{YCT}}{\mathrm{ARFT}}
$$

in which,

$\mathrm{RAE}=$ Agronomic efficiency in $\mathrm{kg}$ of seeds per $\mathrm{kg}$ of nutrient applied;

YFT $=$ Yield in treatment fertilized with $\mathrm{P}, \mathrm{kg} \mathrm{ha}^{-1}$; $\mathrm{YCT}=$ Yield in control treatment, $\mathrm{kg} \mathrm{ha}^{-1}$;

ARFT $=$ Application rate in treatment fertilized with $\mathrm{P}$, $\mathrm{kg} \mathrm{ha}^{-1}$.

The harvest index in \% ((seeds weight/shoot biomass weight) $\mathrm{x} 100$ ) was also evaluated; the results were adjusted to the Gaussian model.

The data were subjected to analysis of variance. After that, depending on significance, the $\mathrm{T}$ test at $5 \%$ probability was used for the qualitative factors; and, for quantitative factors, adjustments of the regression model were made, which were chosen based on significance of the regression coefficients and on the potential to explain the biological phenomenon in question. Statistical analysis was made with the SISVAR 5.3 statistical software (Ferreira, 2011).

\section{RESULTS AND DISCUSSION}

The production characteristics of stem, leaf, and shoot dry matter and 100 seed weight were influenced $(p<0.05)$ by the molybdenum application factor (Table 1$)$. Isolated application of phosphorus $(\mathrm{P})$ rates significantly affected the characteristics of stem, seed, and shoot dry matter and number of seed per plant. Significant interaction ( $p>0.05)$ was not found between the factors of molybdenum application $\mathrm{x}$ phosphorus application rates for the chickpea production characteristics.

Leaf fertilization with molybdenum led to higher production of stems and shoot dry matter compared to plants that did not receive molybdenum through 
fertilization (Table 2). Such results indicate greater mineral nutritional balance with molybdenum in cultivation of chickpea, after fertilization, especially since it is a nutrient responsible for an increase in activity of the enzymes nitrogenase and nitrate reductase, which are involved in biological fixation and assimilation of $\mathrm{N}$, increasing the production of photoassimilates and the accumulation of shoot biomass. In the edible bean crop, leaf application of molybdenum also had a positive effect on shoot dry matter and productivity, which can be attributed to greater enzyme activity that strengthens nitrate assimilation by plants (Nascimento et al., 2009; Lopes et al., 2014; Lopes et al., 2016).

The use of molybdenum on edible bean seeds ( $3 \mathrm{~g} \mathrm{~kg}^{-1}$ seeds), also increased shoot dry matter production by $3.91 \mathrm{~g}$ (Matoso; Kusdra, 2014). Oliveira et al. (2017), in the soybean crop, concluded that application rates of Mo from 25 to $50 \mathrm{~g} \mathrm{ha}^{-1}$ through the leaves are sufficient to increase yield. However, fertilization with molybdenum did not change dry matter production of leaves and seeds or seeds per plant (Table 2), indicating lower demand of molybdenum for chickpea production or adequate natural supply of this nutrient via soil. Fertilization with nitrogen in the crop may have contributed to obtain this result because the way of supplying nitrogen changes molybdenum uptake by plants. For Araujo et al. (2009), under conditions of good $\mathrm{N}$ availability, both in sowing and in topdressing, the application rate of Mo necessary to obtain maximum production of pods per edible bean plant was lower, indicating lower response from molybdenum fertilization. The application of Mo combined with rhizobia inoculation can be used as a solution for making Mo available to plants (Marschner, 2012).

However, only the 100 seed weight variable was higher in the absence of application of leaf molybdenum. In studies with edible bean (BRSMG Majestoso), Vieira et al. (2016) concluded that molybdenum is more effective when applied in the pod formation phase, resulting in higher results in content for the seed. In the present study, molybdenum fertilization was carried out near 20 DAE and did not contribute to the increase of the seeds weight. Molybdenum leaf fertilization contributed to higher production of stems and shoot dry matter,

Table 1: Summary of analysis of variance for stem dry matter, leaf dry matter, seed yield (Yeld), shoot dry matter (Shoot), 100 seeds weight (W100), and number of seeds per plant of chickpea after application of phosphorus rates and leaf application of molybdenum.

\begin{tabular}{cccccccc}
\hline \multirow{2}{*}{ S.V. } & \multirow{7}{c}{ DF } & \multicolumn{7}{c}{ Mean square } \\
\cline { 3 - 7 } & & Stems & Leaves & Yield & Shoot & W100 & Seeds/plant \\
\hline Block & 3 & $0.56^{\text {ns }}$ & $0.02^{\text {ns }}$ & $0.76^{\text {ns }}$ & $2.85^{*}$ & $5.44^{\text {ns }}$ & $19.16^{\text {ns }}$ \\
Molybdenum (M) & 1 & $4.13^{*}$ & $0.15^{*}$ & $0.00^{\text {ns }}$ & $6.06^{*}$ & $27.85^{*}$ & $0.06^{\text {ns }}$ \\
P Rates (P) & 4 & $3.25^{*}$ & $0.07^{\text {ns }}$ & $2.63^{*}$ & $11.88^{*}$ & $2.98^{\text {ns }}$ & $65.85^{*}$ \\
M x P & 4 & $0.64^{\text {ns }}$ & $0.05^{\text {ns }}$ & $0.25^{\text {ns }}$ & $0.58^{\text {ns }}$ & $10.33^{\text {ns }}$ & $6.47^{\text {ns }}$ \\
Residue & 27 & 0.56 & 0.03 & 0.38 & 0.85 & 4.11 & 9.56 \\
Mean & & 5.43 & 1.24 & 2.48 & 9.15 & 32.73 & 12.40 \\
CV (\%) & & 13.82 & 15.75 & 24.95 & 10.09 & 6.20 & 24.95 \\
\hline
\end{tabular}

ns, ${ }^{*}$ : not significant and significant at $5 \%$ by the F test, respectively. S.V.: Source of variation; DF: degrees of freedom; C.V.: coefficient of variation in percentage.

Table 2: Stem dry matter (Stems), leaf dry matter (Leaves), seed yield (Seeds), shoot dry matter (Shoot), 100 seed weight (W100), and seed per plant (Seeds/plant) of chickpea, without or with leaf application of molybdenum.

\begin{tabular}{|c|c|c|c|c|c|c|}
\hline Molybdenum & Stems & Leaves & Seeds & Shoot & W100 & Seeds/plant \\
\hline & \multicolumn{4}{|c|}{------------------------t ha-1------------------- } & -----g----- & ------g------ \\
\hline Without & $5.11 b$ & $1.18 \mathrm{a}$ & $2.47 a$ & $8.76 \mathrm{~b}$ & $33.57 a$ & $12.36 a$ \\
\hline With & $5.75 a$ & $1.30 a$ & $2.49 a$ & 9.54a & $31.90 \mathrm{~b}$ & $12.44 a$ \\
\hline
\end{tabular}

Mean values followed by the same letter in the column do not differ among themselves by the $t$ test $(p<0.05)$. 
indicating the greater allocation of photoassimilates in vegetative organs of the chickpea in detriment to the 100 seed weight. Qin et al. (2017) mention that Mo plays important roles in the growth and metabolism of plants as a constituent of various enzymes, such as nitrate reductase, sulfite oxidase, xanthine dehydrogenase, aldehyde oxidase, and the mitochondrial amidoxime reductase, in these enzymes Mo is directly involved in nitrate assimilation, sulfite detoxification, purine degradation and synthesis of abscisic acid (ABA).
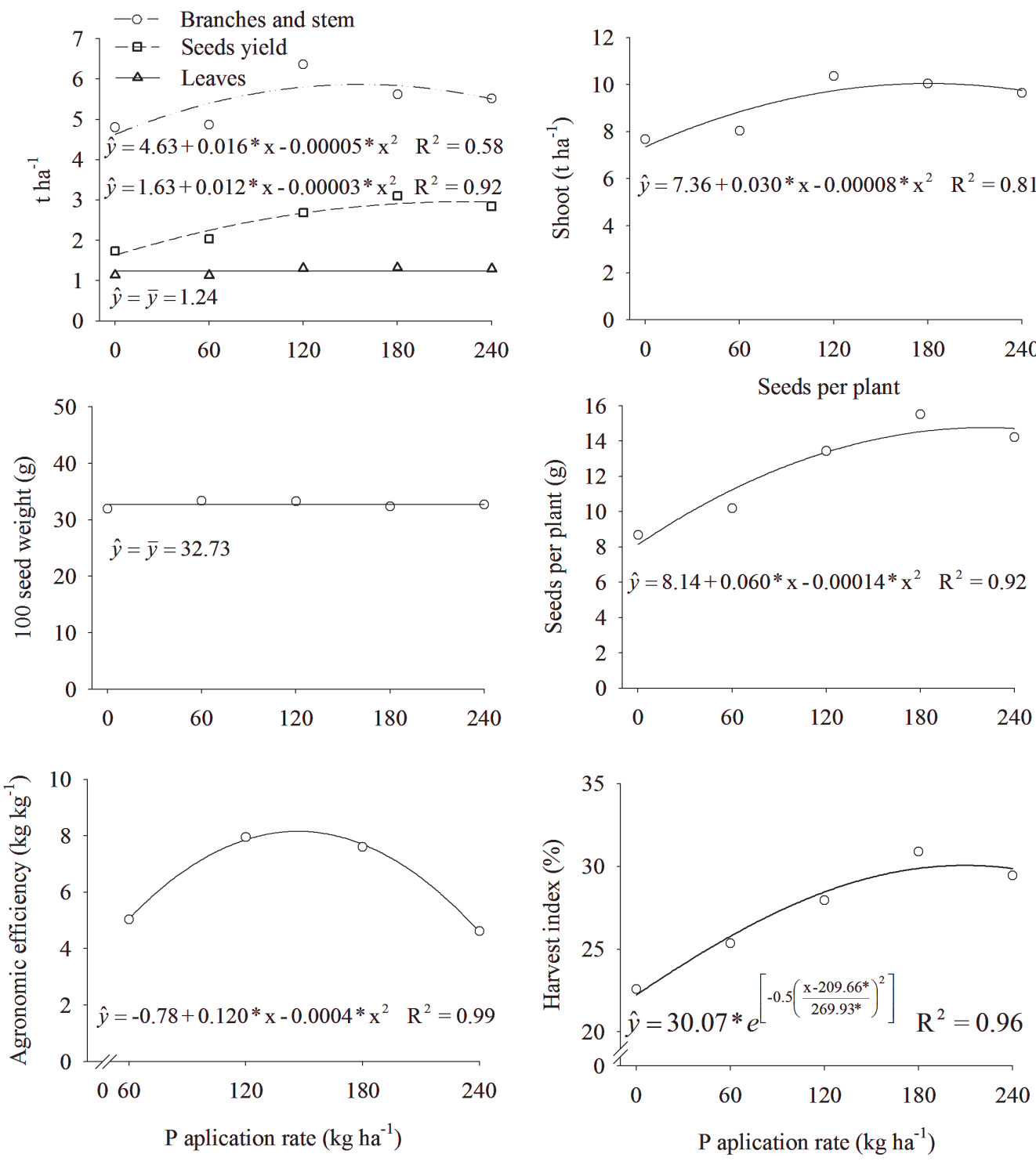

Figure 2: Stem dry matter, leaf dry matter, seed yield, shoot dry matter, 100 seed weight (W100), and seed per plant, agronomic efficiency, and harvest index of chickpea after fertilization at different rates of phosphorus. *, significant at $5 \%$ by the $t$ test. 
The phosphorus application rate found in this study to obtain maximum yield was also considered high (200 kg ha $\left.{ }^{-1}\right)$ compared to the results found in the literature. Neenu et al. (2014) studied the response of chickpea genotypes under $\mathrm{P}$ application rates and reported that rates from 60 to $90 \mathrm{~kg} \mathrm{ha}^{-1} \mathrm{P}_{2} \mathrm{O}_{5}$ are favorable to root development and, consequently, to biological nitrogen fixation. Gulpadiya et al. (2014) and Pingoliya et al. (2014) also obtained higher growth and seed yield after application of 60 to $90 \mathrm{~kg} \mathrm{ha}^{-1}$ of $\mathrm{P}_{2} \mathrm{O}_{5}$. This difference in the $\mathrm{P}$ rate may have occurred because Brazilian soils are oxidic, exhibiting high capacity for specific adsorption of $\mathrm{P}$, a phenomenon exacerbated by mineral fractions of clay in the soil (Vilar et al., 2010; Novais; Smyth, 1999).

Dry matter of the shoot part increased $\left(10.17 \mathrm{tha}^{-1}\right)$ up to a rate of $187.5 \mathrm{~kg} \mathrm{ha}^{-1} \mathrm{P}_{2} \mathrm{O}_{5}$ (Figure 2). Mean production of leaf dry matter and 100 seed weight was $1.24 \mathrm{t} \mathrm{ha}^{-1}$ and $32.73 \mathrm{~g}$ (Figure 2), and neither was affected by differing $P$ application rates. Nevertheless, phosphorus application increased seed weight from $7.36 \mathrm{~g}$ per plant at the zero rate to $14.56 \mathrm{~g}$ per plant with the application of $214.28 \mathrm{~kg}$ $\mathrm{ha}^{-1}$ of $\mathrm{P}_{2} \mathrm{O}_{5}$. This indicates that phosphorus fertilization was fundamental for obtaining a higher number of seeds per plant and higher yield of chickpea.

Maximum agronomic efficiency of $8,3 \mathrm{~kg}$ seeds per $\mathrm{kg}$ of nutrient applied was obtained after application of $150 \mathrm{~kg} \mathrm{ha}^{-1} \mathrm{P}_{2} \mathrm{O}_{5}$ (Figure 2), indicating that application rates of $150 \mathrm{~kg} \mathrm{ha}^{-1} \mathrm{P}_{2} \mathrm{O}_{5}$ may be recommended for growing irrigated chickpea in the Brazilian semi-arid region, because this rate led to expressive results in dry matter and yield, with greater efficiency in P use. In contrast, the maximum harvest index of 30.07 was obtained at the application rate of $209.66 \mathrm{~kg} \mathrm{ha}^{-1} \mathrm{P}_{2} \mathrm{O}_{5}$, a rate higher than that found for maximum agronomic efficiency. This harvest index was near that found by Gulpadiya et al. (2014), 30.68, at a much lower application rate $\left(90 \mathrm{~kg} \mathrm{ha}^{-1} \mathrm{P}_{2} \mathrm{O}_{5}\right)$ than the rate reported in this study $\left(209.66 \mathrm{~kg} \mathrm{ha}^{-1}\right)$. Yet, at the application rate of $150 \mathrm{~kg} \mathrm{ha}^{-1} \mathrm{P}_{2} \mathrm{O}_{5}$, there is also a high harvest index, which can ensure the profitability of chickpea.

In general, $\mathrm{P}_{2} \mathrm{O}_{5}$ application rates from 150 to 200 $\mathrm{kg} \mathrm{ha}^{-1}$ made it possible to obtain high agronomic indices in chickpea. Neenu et al. (2014) found that when they applied $90 \mathrm{~kg} \mathrm{ha}^{-1} \mathrm{P}_{2} \mathrm{O}_{5}$ on a Vertisols, $\mathrm{P}$ uptake by seeds was high, corroborating data of Singh and Singh (2012). Togay et al. (2008b) also evaluated the response of chickpea under P application rates and found rates lower than those reported in the present study, perhaps because this study works with tropical soils, and phosphorus is more adsorbed to clay complexes. Results may also be related to the level of technology and the cultivar used by the authors.
After fertilizations with phosphorus and molybdenum, at the end of growing chickpea, soil samples were collected in the row and between plant rows for evaluation of soil chemical attributes (Table 3). Significant changes $(\mathrm{p}<0.05)$ were found in most of the chemical attributes of the soil collected in the crop row compared to those found between the rows. The phosphorus application rates brought about changes in $\mathrm{pH}$ and concentrations of $\mathrm{P}$ and $\mathrm{Ca}$ in the soil in the crop row; however, the use of Mo did not affect soil attributes.

In the soil in the crop row, higher concentrations were obtained of $\mathrm{P}, \mathrm{K}, \mathrm{H}+\mathrm{Al}$, and Prem, and reduction in $\mathrm{pH}\left(\mathrm{H}_{2} \mathrm{O}\right)$ and $\mathrm{Ca}$ concentration, $\mathrm{SB}, \mathrm{t}$, and $\mathrm{V}$ compared to the soil between the rows (Table 4). Such results were attributed to biological rhizosphere phenomena and to localized fertilization with single superphosphate, potassium chloride, and urea. Greater biological activity of the plant root system and of rhizospheric microorganisms may have contributed to release of organic (low molecular weight organic acids) and inorganic $\left(\mathrm{H}^{+}\right)$compounds able to reduce $\mathrm{pH}, \mathrm{V}, \mathrm{Ca}$ concentrations, and SB, and increase potential acidity of the soil located in the plant row.

Chickpea plants have high cation uptake capacity and acidification of the rhizosphere, decreasing $\mathrm{pH}$ from 5 to 4.3, compared to the rhizosphere condition of other plant species, such as wheat and pea (Wang et al., 2016). In soils with $\mathrm{pH}$ above 7.3, application of single superphosphate $\left(\mathrm{Ca}\left(\mathrm{H}_{2} \mathrm{PO}_{4}\right)_{2} \cdot \mathrm{H}_{2} \mathrm{O}+\mathrm{CaSO}_{4} \cdot 2 \mathrm{H}_{2} \mathrm{O}\right)$ leads to their acidification (Ali et al., 2014), due to dissociation reactions of $\mathrm{H}_{2} \mathrm{PO}_{4}^{-}$to $\mathrm{HPO}_{4}^{2-}$, releasing $\mathrm{H}^{+}$ions in the soil solution. Acidification is also an indirect consequence of the increase in the concentration of sulfate in the soil solution (Rosado et al., 2014). Oliveira et al. (2014) found decrease in the $\mathrm{pH}$ of electronegative soils up to $10 \mathrm{~cm}$ from the location of potassium chloride $(\mathrm{KCl})$ granules; this decrease in $\mathrm{pH}$ was mainly attributed to increase in the density of electric charges at the surface of the electronegative colloids of the soils, due to the increase in electrolytic concentration, releasing ions of an acidic nature to the soil solution.

Enzymatic reactions related to transformation of the $\mathrm{N}$ derived from urea bring about soil acidification (Ghimire et al., 2017). In initial periods after fertilization (first 15 days), the ammonium $\left(\mathrm{NH}_{4}^{+}\right)$mineralization process causes a small increase in soil $\mathrm{pH}$. This alkaline reaction is rapidly suppressed by nitrification (oxidation of the ammonium to nitrate), leading to release of a greater proportion of $\mathrm{H}^{+}$and increase in the concentration of $\mathrm{Al}^{3+}$ in the soil solution (Mehmood et al. 2017), ions responsible for acidification of the $\mathrm{pH}$. 
Table 3: Summary of analysis of variance obtained for the chemical attributes of soil from the crop row and between the rows (A), after leaf application of molybdenum (Mo) (with and without molybdenum) and phosphorus application rates (PAR) in chickpea.

\begin{tabular}{|c|c|c|c|c|c|c|c|}
\hline \multirow{2}{*}{ S.V. } & \multirow{2}{*}{ DF } & \multicolumn{6}{|c|}{ Mean square } \\
\hline & & $\mathrm{pH}$ & OC & $\mathrm{P}$ & $\mathrm{K}$ & $\mathrm{Ca}$ & $\mathrm{Mg}$ \\
\hline Block & 3 & $0.06 *$ & $1.37^{\star}$ & $665.78^{\text {ns }}$ & $1056.84^{\text {ns }}$ & $0.32^{\text {ns }}$ & $1.90^{\text {ns }}$ \\
\hline Sampling (A) & 1 & $0.06 *$ & $0.04^{\mathrm{ns}}$ & $76020.61 *$ & $2773.01 *$ & $0.93 *$ & $0.31^{\mathrm{ns}}$ \\
\hline Molybdenum (Mo) & 1 & $0.00^{\text {ns }}$ & $0.14^{\mathrm{ns}}$ & $554.19^{\text {ns }}$ & $1.51^{\mathrm{ns}}$ & $0.10^{\text {ns }}$ & $0.09^{\text {ns }}$ \\
\hline$P$ rates $(P)$ & 4 & $0.03 *$ & $0.02^{\text {ns }}$ & $11252.01 *$ & $50.01^{\text {ns }}$ & $0.06^{\mathrm{ns}}$ & $0.12^{\text {ns }}$ \\
\hline Mo x A & 1 & $0.05 *$ & $0.00^{\text {ns }}$ & $2497.61 *$ & $365.51^{\mathrm{ns}}$ & $0.01^{\mathrm{ns}}$ & $0.16^{\mathrm{ns}}$ \\
\hline Mo $\times P$ & 4 & $0.01^{\mathrm{ns}}$ & $0.02^{\text {ns }}$ & $205.81^{\mathrm{ns}}$ & $476.04^{\mathrm{ns}}$ & $0.27^{\mathrm{ns}}$ & $0.23^{\text {ns }}$ \\
\hline$A \times P$ & 4 & $0.04 *$ & $0.02^{\text {ns }}$ & $8964.65^{*}$ & $408.16^{n s}$ & $0.13^{\text {ns }}$ & $0.25^{\mathrm{ns}}$ \\
\hline Mo $\times A \times P$ & 4 & $0.01^{\mathrm{ns}}$ & $0.05^{\text {ns }}$ & $148.48^{\text {ns }}$ & $173.41^{\mathrm{ns}}$ & $0.12^{\text {ns }}$ & $0.16^{\mathrm{ns}}$ \\
\hline Residue & 57 & 0.01 & 0.05 & 415.51 & 591.91 & 0.16 & 0.19 \\
\hline Mean & & 7.56 & 1.93 & 51.36 & 186.71 & 8.64 & 1.83 \\
\hline \multirow[t]{2}{*}{ CV (\%) } & & 1.56 & 11.81 & 39.59 & 13.03 & 4.66 & 24.00 \\
\hline & & $\mathrm{H}+\mathrm{Al}$ & SB & $\mathrm{t}$ & $\mathrm{T}$ & $\mathrm{V}$ & Prem \\
\hline Block & 3 & $2.65^{\star}$ & $2.55^{\star}$ & $2.55^{\star}$ & $1.40^{*}$ & $170.32 *$ & $106.74 *$ \\
\hline Sampling (A) & 1 & $0.88^{*}$ & $1.95 *$ & $1.95 *$ & $0.21^{\mathrm{ns}}$ & $59.53 *$ & $50.46^{*}$ \\
\hline Molybdenum (Mo) & 1 & $0.03^{\text {ns }}$ & $0.01^{\mathrm{ns}}$ & $0.01^{\mathrm{ns}}$ & $0.02^{\text {ns }}$ & $1.76^{\text {ns }}$ & $1.65^{\mathrm{ns}}$ \\
\hline$P$ rates $(P)$ & 4 & $0.07^{\mathrm{ns}}$ & $0.28^{\mathrm{ns}}$ & $0.28^{\text {ns }}$ & $0.42^{\text {ns }}$ & $3.90^{\text {ns }}$ & $6.80^{\text {ns }}$ \\
\hline Mo x A & 1 & $0.00^{\text {ns }}$ & $0.05^{\mathrm{ns}}$ & $0.05^{\text {ns }}$ & $0.04^{\mathrm{ns}}$ & $0.09^{n s}$ & $5.59^{\text {ns }}$ \\
\hline Mo $\times P$ & 4 & $0.04^{\mathrm{ns}}$ & $0.39^{\text {ns }}$ & $0.39^{\text {ns }}$ & $0.53^{\text {ns }}$ & $2.01^{\mathrm{ns}}$ & $8.46^{\text {ns }}$ \\
\hline$A \times P$ & 4 & $0.04^{\text {ns }}$ & $0.58^{\text {ns }}$ & $0.58^{\text {ns }}$ & $0.64^{*}$ & $2.80^{\text {ns }}$ & $3.95^{\text {ns }}$ \\
\hline Mo $\times A \times P A R$ & 4 & $0.02^{\text {ns }}$ & $0.11^{\mathrm{ns}}$ & $0.11^{\mathrm{ns}}$ & $0.13^{\text {ns }}$ & $1.52^{\mathrm{ns}}$ & $2.68^{\text {ns }}$ \\
\hline Residue & 57 & 0.03 & 0.23 & 0.23 & 0.21 & 2.56 & 5.31 \\
\hline Mean & & 1.11 & 10.95 & 10.95 & 12.06 & 90.78 & 30.91 \\
\hline CV(\%) & & 17.35 & 4.47 & 4.47 & 3.88 & 1.96 & 7.46 \\
\hline
\end{tabular}

ns,**** not significant and significant at $5 \%$ by the F test, respectively. SV: Source of variation; DF: degrees of freedom; C.V.: coefficient of variation in percentage.

Table 4: Chemical attributes of the soil collected in the crop row and between the rows and after harvest of chickpea.

\begin{tabular}{|c|c|c|c|c|c|c|}
\hline Sampling & $\mathrm{pH}$ & OC & $\mathrm{P}$ & $\mathrm{K}$ & $\mathrm{Ca}$ & $\mathrm{Mg}$ \\
\hline & $\mathrm{H}_{2} \mathrm{O}$ & dag kg-1 & \multicolumn{2}{|c|}{-------mg dm³------- } & \multicolumn{2}{|c|}{$-----\mathrm{cmol}_{\mathrm{c}} \mathrm{dm}^{-3}$} \\
\hline Row & $7.53 b$ & $1.90 a$ & $82.18 \mathrm{a}$ & 192.60a & $8.53 b$ & $1.76 a$ \\
\hline \multirow[t]{3}{*}{ Between rows } & $7.59 a$ & $1.95 a$ & $20.53 b$ & $180.83 b$ & $8.75 a$ & $1.89 a$ \\
\hline & $\mathrm{H}+\mathrm{Al}$ & SB & $\mathrm{t}$ & $\mathrm{T}$ & $\mathrm{V}$ & Prem \\
\hline & \multicolumn{4}{|c|}{ 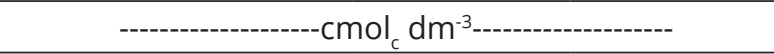 } & $\%$ & $\mathrm{mg} \mathrm{L}^{-1}$ \\
\hline Row & $1.22 \mathrm{a}$ & $10.79 b$ & $10.79 b$ & $12.01 a$ & $89.91 b$ & $31.70 a$ \\
\hline Between rows & $1.01 \mathrm{~b}$ & $11.10 \mathrm{a}$ & $11.10 \mathrm{a}$ & $12.11 \mathrm{a}$ & $91.64 a$ & $30.12 b$ \\
\hline
\end{tabular}

Mean values followed by the same letter in the column do not differ among themselves by the $F$ test $(p<0.05)$. 
The changes observed in the soil chemical attributes in the crop row can be summed up in the following factors: i) high capacity of cation uptake by plants over the chickpea growing season; ii) greater movement of cations in the soil profile due to formation of ionic complexes with sulfate coming from fertilization with single superphosphate; iii) soil acidification; and iv) formation of precipitates with other soil anions.

The formation of calcium phosphate precipitates may also have contributed to decrease in $\mathrm{pH}, \mathrm{V}, \mathrm{Ca}$ concentration, and SB and an increase in potential acidity in the soil of the crop row, due to the precipitation reaction described by Ernani (2016): $3 \mathrm{Ca}^{2+}+2 \mathrm{H}_{2} \mathrm{PO}_{4}^{-}=>\mathrm{Ca}_{3}\left(\mathrm{PO}_{4}\right)^{2+} 4 \mathrm{H}^{+}$. The product of this reaction releases $4 \mathrm{H}^{+}$to the soil solution and temporarily reduces availability of $\mathrm{Ca}$ and $\mathrm{P}$ to plants.

$\mathrm{P}$ application in the crop row increased $\mathrm{P}$ concentration and $\mathrm{T}$ in a linear manner, and reduced soil $\mathrm{pH}$ (Figure 3). For each $100 \mathrm{~kg}$ of phosphorus added, a reduction of 0.09 units of $\mathrm{pH}$ in the soil were obtained. In the soil from between the crop rows, phosphorus fertilization did not change these attributes. Ali et al. (2014) showed that rates of application of single superphosphate (from zero to $150 \mathrm{~kg} \mathrm{ha}^{-1} \mathrm{P}_{2} \mathrm{O}_{5}$ ) in soil with $\mathrm{pH}\left(\mathrm{H}_{2} \mathrm{O}\right)$ of 7.73 brought about a reduction of 0.17 units of $\mathrm{pH}$ for every $100 \mathrm{~kg} \mathrm{P}_{2} \mathrm{O}_{5}$ applied. The reduction in soil $\mathrm{pH}$ was attributed to release of $\mathrm{H}^{+}$ ions derived from the chemical equilibrium reaction between the two main soluble forms of phosphate $\left(\mathrm{H}_{2} \mathrm{PO}_{4}^{-}+\mathrm{H}_{2} \mathrm{O}=\mathrm{HPO}_{4}{ }^{2-}+\mathrm{H}^{+}\right)$, whose acid dissociation constant is $6.2 \times 10^{-8}$, which results in a $\mathrm{pK}_{\mathrm{a}}$ (potential of the dissociation constant) of 7.21 (Oliveira et al., 2014). In our study, soil $\mathrm{pH}$ was greater than 7.21 (Figure 3 ); thus, the equilibrium reaction brings about predominance of $\mathrm{HPO}_{4}^{2-}$ and the release of $\mathrm{H}^{+}$ions in the soil solution after fertilization with single superphosphate. This reaction was considered positive for plant development, due to reduction in soil alkalinity.

The increase in the application rates of single superphosphate also increased total cation exchange capacity (T) in the soil located in the crop row (Figure 3), exhibiting maximum $\mathrm{T}$ of $11.11 \mathrm{cmol}_{\mathrm{c}} \mathrm{dm}^{-3}$ at the rate of $240 \mathrm{~kg} \mathrm{ha}^{-1} \mathrm{P}_{2} \mathrm{O}_{5}$. This result was attributed to the buffering effect of the fertilizer, contributing to an increase in the presence/manifestation of variable charges, dependent on $\mathrm{pH}$, which is very common in soils of tropical origin.
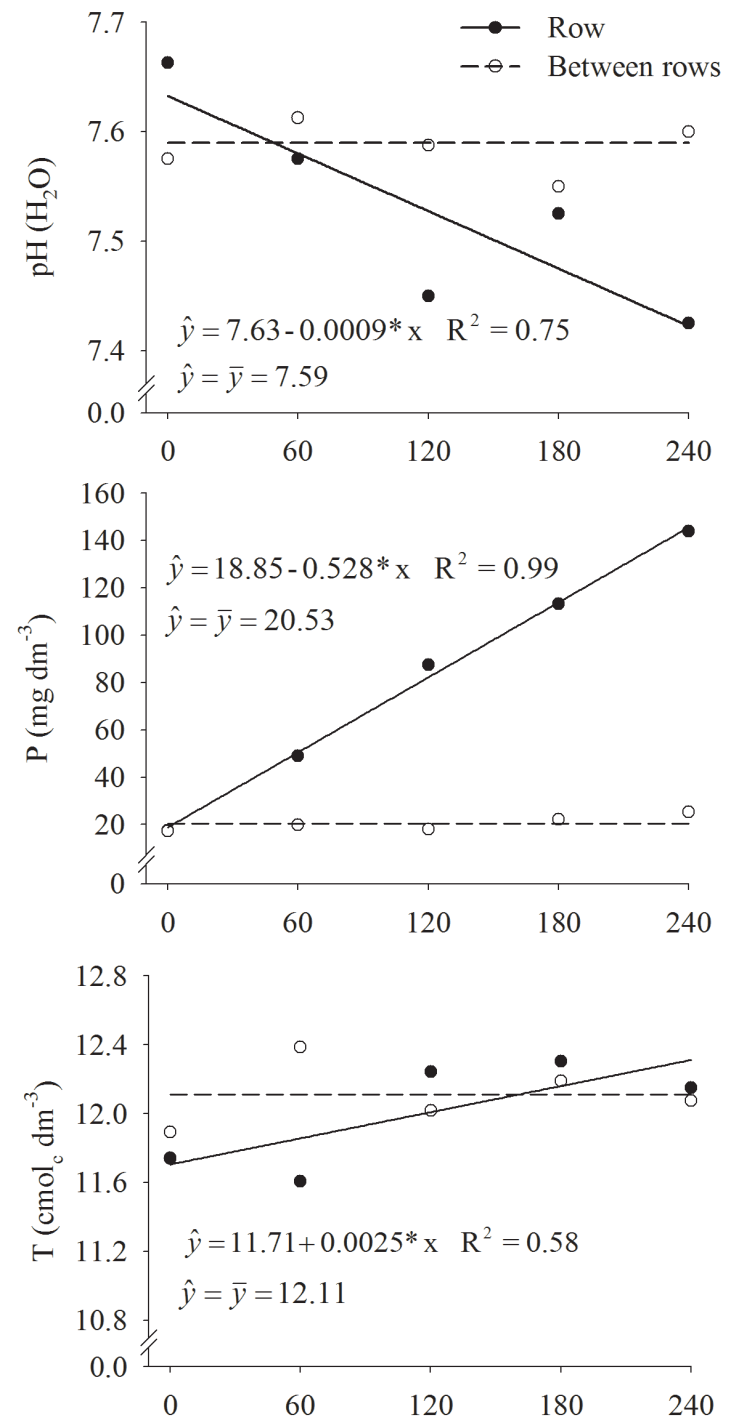

Figure 3: Chemical characteristics, $\mathrm{pH}\left(\mathrm{H}_{2} \mathrm{O}\right), \mathrm{P}$, and total cation exchange capacity (T) obtained in soil from the crop row and between crop rows of chickpea, after fertilization with different rates of $P$ in the form of single superphosphate. *, significant at $5 \%$ by the $t$ test.

\section{CONCLUSIONS}

The yield of $2.71 \mathrm{t} \mathrm{ha}^{-1}$ chickpea is obtained from fertilization of $200 \mathrm{~kg} \mathrm{ha}^{-1} \mathrm{P}_{2} \mathrm{O}_{5}$. The application of 150 $\mathrm{kg} \mathrm{ha}^{-1} \mathrm{P}_{2} \mathrm{O}_{5}$ promotes maximum agronomic efficiency of chickpea. Application of molybdenum increases aboveground dry matter of chickpea and does not change soil chemical attributes. Application of $\mathrm{P}$ in the form of single superphosphate reduces soil $\mathrm{pH}$ and increases the concentrations of $\mathrm{P}$ and $\mathrm{T}$ only in the crop row of chickpea. 


\section{ACKNOWLEDGMENTS}

The authors thank the Foundation for Research Support of Minas Gerais (FAPEMIG) and National Council for Scientific and Technological Development (CNPq), for the financial support and scholarships to the authors.

\section{REFERENCES}

ALI, F. et al. Effect of applied phosphorus on the availability of micronutrients in alkaline-calcareous soil. Journal of Environment and Earth Science, 4(15):143-147, 2014.

ALVARES, C. A. et al. Köppen's climate classification map for Brazil. Meteorologische Zeitschrift, 22(6):711-728, 2013.

ARAÚJO, P. R. A. et al. Combinações de doses de molibdênio e nitrogênio na adubação da cultura do feijoeiro-comum. Acta Scientiarum Agronomy, 31(2):227-234, 2009.

ARAÚJO, A. P.; MACHADO, C. D. T. Fósforo. In: FERNANDES, M. S. Nutrição mineral de plantas. Viçosa, MG: Sociedade Brasileira de Ciência do Solo, 2006, p.251-280.

ARTIAGA, O. P. et al. Avaliação de genótipos de grão de bico em cultivo de sequeiro nas condições de Cerrado. Revista Brasileira Ciência Agrária, 10(1):102-109, 2015.

BALAI, K. et al. Effect of phosphorus, and zinc on growth, yield and economics of chickpea (Cicer aritinum L.). International Journal of Current Microbiology and Applied Sciences, 6(3):1174-1181, 2017.

BHUIYAN, M. M. H. et al. Effect of phosphorus, molybdenum and rhizobium inoculation on growth and nodulation of mungbean. Journal of Soil and Nature, 2(2):25-30, 2008.

BIDYARANI, N. et al. Enhancement of plant growth and yields in Chickpea (Cicer arietinum L.) through novel cyanobacterial and biofilmed inoculants. Microbiological Research, 188:97-105, 2016.

CHAGAS, J. M. et al. Feijão. In: Ribeiro, A. C. et al. (Ed.) Recomendações para o uso de corretivos e fertilizantes em Minas Gerais: $5^{\mathbf{a}}$ aproximação. Viçosa, MG: Comissão de Fertilidade do Solo do Estado de Minas Gerais, 1999. p.306-307.

DAS, A. K. et al. Effect of phosphorus fertilizeron the dry matter accumulation, nodulation and yield in chickpea. Bangladesh Research Publications Journal, 1:47-60, 2008.

ERNANI, P. R. Química do solo e disponibilidade de nutrientes. 2. ed. Lages: Do Autor, 2016. 256p.
FERREIRA, D. F. Sisvar: A computer statistical analysis system. Ciência e Agrotecnologia, 35(6):1039-1042, 2011.

GAZOLA, R. N. et al. Efeito residual da aplicação de fosfato monoamônio revestido por diferentes polímeros na cultura de milho. Revista Ceres, 60(6):876-884, 2013.

GHIMIRE, R.; MACHADO, S.; BISTA, P. Soil pH, Soil organic matter, and crop yields in winter wheat-summer fallow systems. Agronomy Journal, 109(2):706-717, 2017.

GULPADIYA, V. K. et al. Effect of varieties and phosphoru slevels on growth and yield of chickpea (Cicer arietinum L.). Journal of Rural and Agricultural Research, 14(1):43-44, 2014.

LARANJO, M.; ALEXANDRE, A.; OLIVEIRA, S. Legume growthpromoting rhizobia: An overview on the Mesorhizobium genus. Microbiological Research, 169(1):2-17, 2014.

LOPES, J. F. et al. Produtividade e composição mineral do feijão em resposta às adubações com molibdênio e níquel. Revista Ceres, 63(3):419-426, 2016.

LOPES, J. F. et al. Adubação foliar com níquel e molibdênio no feijoeiro comum cv. Ouro Vermelho. Revista Ceres, 61(2):155-160, 2014.

MARSCHNER, P. Marschner's mineral nutrition of higher plants. Academic Press. v.89. 2012, 649p.

MATOSO, S. C.; KUSDRA, J. F. Nodulação e crescimento do feijoeiro em resposta à aplicação de molibdênio e inoculante rizobiano. Revista Brasileira de Engenharia Agrícola e Ambiental, 18(6):567-573, 2014.

MEHMOOD, K. et al. Amelioration of an acidic ultisol by strawderived biochars combined with dicyandiamide under application of urea. Environmental Science and Pollution Research, 24(7):6698-6709, 2017.

NASCIMENTO, W. M. Hortaliças Leguminosas. Brasília: Empresa Brasileira de Pesquisa Agropecuária, 232p, 2016.

NASCIMENTO, W. M. et al. BRS Aleppo: Grão-de-bico. Maior tolerância a fungos de solo. Brasília: Embrapa Hortaliças, $4 p, 2014$.

NASCIMENTO, M. S. et al. Nitrogênio em cobertura e molibdênio via foliar em feijoeiro de inverno no sistema plantio direto - Características agronômicas e produtividade. Scientia Agraria, 10(5):351-358, 2009.

NAWAZ, F. et al. Yield and yield components of chickpea as affected by various levels of FYM and rhizobium inoculation. Pure and Applied Biology, 6(1):346-351, 2017. 
NEENU, S. et al. Growth and yield of different varieties of chickpea (Cicer arietinum L.) as influenced by the phosphorus nutrition under rainfed conditions on Vertisols. International Journal of Bio-resource and Stress Management, 5(1):53-57, 2014.

NOVAIS, R. F.; SMYTH, T. J. Fósforo em solo e planta em condições tropicais. Viçosa: Universidade Federal de Viçosa, 399p, 1999.

OLIVEIRA, C. et al. Produção de sementes de soja enriquecidas com molibdênio. Revista Ceres, 64(3):282-290, 2017.

OLIVEIRA, J. P. M. et al. Alterações químicas e avaliação de P disponível na região adjacente aos grânulos de superfosfato triplo e diamônio fosfato em solos ácidos. Revista Brasileira de Ciência do Solo, 38(5):1526-1536, 2014.

PINGOLIYA, K. K. et al. Effect of phosphorus and iron levels on growth and yield attributes of chickpea (Cicer arietinum L.) under agroclimatic zone IV A of Rajasthan, India. Legume Research, 37(5):537-541, 2014.

QIN, S. et al. Effect of molybdenum levels on photosynthetic characteristics, yield and seed quality of two oilseed rape (Brassica napus L.) cultivars. Soil Science and Plant Nutrition, 63(2):137-144, 2017.

RANI, B. S.; KRISHNA, T. G. Response of chickpea (Cicer arietinum L.) varieties to nitrogenon a calcareous vertisols. Indian Journal of Agricultural Research, 50(3):278-281, 2016.

ROSADO, T. L. et al. The effect of sources and application doses of nitrogen on the chemical properties of an oxisol cultivated with guinea grass. Revista Brasileira de Ciência do Solo, 38(3):840-849, 2014.

SINGH, D.; SINGH, H. Effect of phosphorus and zinc nutrition on yield, nutrient uptake and quality of chickpea. Annals of Plant and Soil Research, 14(1):71-74, 2012.

TAIZ, L.; ZEIGER, E. Fisiologia vegetal. 5. ed. Porto Alegre: Artimed, 2013, 918p.

TOGAY, Y.; TOGAY, N.; DOGAN, Y. Research on the effect of phosphorus and molybdenum applications on the yield and yield parameters in lentil (Lens culinaris Medic.). African Journal of Biotechnology, 7(9):1256-1260, 2008a.

TOGAY, N. et al. Effects of rhizobium inoculation, sulfur and phosphorus applications on yield, yield components and nutrient uptakes in chickpea (Cicer arietinum L.). African Jornal of Biotechnology, 7(6):776-782,2008b.

VIEIRA, R. F. et al. Split application of molybdic fertilizer at the reproductive stage of common bean increases the molybdenum content in seed. Acta Scientiarum. Agronomy, 38(4):529-533, 2016.

VILAR, C. et al. Capacidade máxima de adsorção de fósforo relacionada a formas de ferro e alumínio em solos subtropicais. Revista Brasileira de Ciência do Solo, 34(4):1059-1068, 2010.

WANG, X. et al. Rhizosphere priming effect on soil organic carbon decomposition under plant species differing in soil acidification and root exudation. New Phytologist, 211(3):864-873, 2016. 